\title{
JUURNAL_RU
}

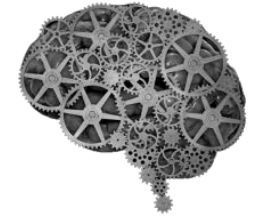

COMPANY GROUP "INTELLEKT"

\author{
Вербицкая Л.П., Писаренко Е.А. \\ Ростовский государственный медииинский университет \\ Областной консультативно-диагностический иентр \\ Ростов-на-Дону, Россия
}

doi: 10.18411/lj2016-3-65

\section{Безопасное детство: актуальные трудности и перспективные возможности}

Спиральная компьютерная томография (СКТ) все шире используется в клинической медицине и обладает целым рядом преимуществ по сравнению с другими методами лучевой диагностики. В последние годы СКТ стала одним из ведущих методов диагностики одонтогенного синусита $[1,2,3]$.

Авторы первых компьютерно-томографических исследований околоносовых пазух указывали на обязательное использование 2-х проекций (аксиальной и коронарной), полагая, что в этом случае удается получить представление о распространенности патологического процесса в трехмерном изображении. Бойко Н.В. и соавт. [4], применив СКТ для диагностики одонтогенного синусита, отметили практическую значимость сагиттальной реконструкции для визуализации взаимоотношений зубов и дна верхнечелюстной пазухи.

Причиной хронических рецидивирующих синуситов нередко является воспалительный процесс в апикальной части корней верхних зубов. Диагностика таких прикорневых поражений сложна, особенно если полость больного зуба вскрыта. В этих случаях КТ в аксиальной и коронарной плоскостях может выявить лишь косвенный признак причастности зубов к возникновению воспаления - утолщение слизистой оболочки дна пазухи в области альвеолярного отростка $[5,6]$. Единственным проявления заболевания в этих 
случаях является длительная головная боль [7]. Традиционные плоскости сканирования зачастую не позволяют оценить взаиморасположение корней зубов и дна верхнечелюстной пазухи, а также состояние костной ткани в переапикальной области, в связи с чем требуется дополнительное исследование, однако, широко используемые в стоматологической практике прицельные рентгенограммы и ортопантограммы не позволяют адекватно оценить анатомические взаимоотношения зубов, периапикальных очагов инфекции и дна верхнечелюстной пазухи [8]. СКТ предусматривает возможность реконструкции изображения в сагиттальной плоскости в точке пересечения линий, отмеченных на аксиальном и коронарном срезах и проходящих через причинный зуб.

Целью нашего исследования было изучение информативности сканирования околоносовых пазух в сагиттальной плоскости у больных с одонтогенными синуситами.

Мы исследовали 34 больных с одонтогенными синуситами.

Всем больным выполнена СКТ на мультиспиральном шестнадцатисрезовом томографе 4-го поколения PHILIPS $\mathrm{MX} 8000$. Исследование проводили в режиме спирального томографирования с толщиной среза 0,75 мм (стандартный режим Sinus/Facial для носа и околоносовых пазух), с последующей обработкой данных с помощью программы многоплоскостных реформаций (MPR) с расстоянием между слоями 1,5 мм.

С учетом клинических проявлений больные были разделены на 2 группы.

В 1 группу вошло 18 больных, у которых связь воспалительного процесса с заболеваниями зубов была очевидна. Наиболее частой причиной возникновения синусита были зубы с осложненным кариозным процессом на верхней челюсти - у 12 больных, причем у 8 больных имело место множественное поражение твердых тканей зубов. У 6 больных развитию ОС предшествовала экстракция зубов, причем у 5 пациентов обнаружено ороантральное сообщение, а у 1 больного развился альвеолит. 
Во 2 группу включено 16 больных, страдающих хроническим верхнечелюстным синуситом длительностью от 1 до 6 лет. У всех больных одонтогенность воспалительного процесса в верхнечелюстной пазухе была неочевидна: у 7 больных клинические проявления впервые появились после перенесенного ОРВИ, у 4 больных поражение верхнечелюстной пазухи не было изолированным, а в процесс были вовлечены решетчатая и лобная пазухи на одноименной стороне, 3 больных были осмотрены стоматологом по направлению лечащего ЛОР врача, однако на основании визуального осмотра санированных зубов было сделано заключение об отсутствии признаков их патологии.

По результатам СКТ у 9 больных были обнаружены инородные тела в пазухах (пломбировочный материал, корни и верхушки корней зубов, дентальные импланты, остеотропный материал) а у 3 больных - радикулярные кисты, у 2 - ретинированные зубы, у 2 - неполная санация зубов при эндодонтических вмешательствах.

Случаи, когда синусит возникает в результате образования одонтогенной кисты (радикулярной или фолликулярной), могут быть правильно идентифицированы только при использовании СКТ. Радикулярные кисты развиваются из эпителиальных гранулем верхушки и корня зуба. При нормальном анатомическом соотношении периодонта и дна верхнечелюстной пазухи киста разрушает дно, проникает в полость пазухи и, по мере увеличения, отодвигает надкостницу вверх. Контакт стенки кисты с надкостницей инициирует процесс новообразования кости. На СКТ эти изменения визуализируются в виде костного ободка вокруг кисты, отделяющего ее от остальной пазухи, и дефекта костной ткани в области альвеолярной бухты, примыкающей к верхушке зуба.

Наше исследование подтверждает, что СКТ околоносовых пазух во многих случаях является единственным методом, позволяющим правильно 
идентифицировать причину хронического синусита с упорным, затяжным течением.

\section{Литература:}

1. Сысолятин С.П., Васильев А.В., Иванов В.И. Сравнительная оценка методов лучевой диагностики одонтогенного верхнечелюстного синусита. Рос ринол. 2011; 2 (19): 18

2. Бойко Н.В., Писаренко Е.А., Морозова Е.Е., Вербицкая Л.П., Колесников В.Н. Диагностика и лечение одонтогенного синусита. Рос. ринол. 2009; 3: 6-10.

3. Бойко Н.В., Максюков С.Ю., Щепляков Д.С., Демидов Ю.Н., Борзилов А.В., Фоменко М.Г. Значение компьютерной томографии для выявления одонтогенного верхнечелюстного синусита. Стоматология для всех. 2015. № 3. C. 16-19.

4. Бойко Н.В., Колесников В.Н., Писаренко Е.А. Диагностические возможности компьютерной томографии околоносовых пазух в сагиттальной проекции. Рос ринол. 2005; 4: С. 10-2.

5. Бойко Н.В., Топоркова С.Ю. Частота бессимптомных кист верхнечелюстных пазух. Рос. ринология. 2014. Т. 22. № 1. С. 15-16.

6. Шулаков В.В., Лежнев Д.А., Бирюлев А.А., Лузина В.В., Лащук С.Ю. Роль патологических изменений полости носа и ее придаточных пазух при хронических одонтогенных верхнечелюстных синуситах. Мед. визуализ. 2014; 3: 93-103.

7. Бойко Н.В., Стагниева И.В. Дифференциальная диагностика лицевых болей. Рос. ринология. 2012. Т. 20. № 4. С. 39-41.

8. Шустова И.В. Комплексный подход к проблеме одонтогенных синуситов. Рос. оторинолар. 2013; 1: 230-4. 